\title{
Pemberdayaan Kader Kesehatan Dalam Deteksi Dini Stunting dan Stimulasi Tumbuh Kembang pada Balita
}

\author{
Fanny Adistie, Valentina Belinda Marlianti Lumbantobing, Nenden Nur Asriyani Maryam \\ Fakultas Keperawatan, Universitas Padjadjaran \\ Email: fanny.adistie@gmail.com
}

\begin{abstract}
Abstrak
Salah satu masalah kesehatan terkait pertumbuhan dan perkembangan pada anak usia balita yang dapat menimbulkan dampak buruk dalam jangka pendek maupun jangka panjang adalah stunting. Saat ini, pemerintah berusaha menanggulangi stunting dengan upaya intervensi gizi spesifik. Agar program tersebut dapat berjalan dengan efektif maka deteksi dini anak dengan stunting penting untuk dilakukan selain pemberian stimulasi tumbuh kembang yang tepat bagi anak. Berdasarkan data Puskesmas Jatinangor di Desa Cipacing terdapat 14 anak yang berada pada status stunting. Tujuan dari kegiatan ini adalah untuk pemberdayaan kader kesehatan dalam deteksi dini stunting serta stimulasi tumbuh kembang pada anak. Sasaran pada kegiatan ini adalah kader kesehatan dengan total sampel sebanyak 31 orang. Kegiatan pemberdayaan berupa satu hari pelatihan yang terbagi dalam 3 sesi dengan menggunakan metode ceramah, diskusi dan tanya jawab serta demonstrasi dan redemonstrasi oleh para kader kesehatan. Hasil kegiatan menunjukkan bahwa terdapat peningkatan pengetahuan para kader kesehatan yaitu sebelum dilakukan kegiatan sebanyak 61,3\% kader memiliki pengetahuan yang baik dan setelah dilakukan kegiatan meningkat menjadi sebanyak 93,5\%. Selain itu, hasil uji statistik menunjukkan terdapat peningkatan yang signifikan pada pengetahuan kader kesehatan setelah dilakukan intervensi $(p=$ 0,000). Namun, untuk aspek psikomotor yang diukur setelah dilakukan pelatihan, didapatkan hampir setengah dari jumlah responden masih berada pada kategori kurang baik. Maka dari itu, diharapkan kegiatan pemberdayaan kader kesehatan dalam deteksi dini stunting serta stimulasi tumbuh kembang pada anak sebaiknya dilakukan secara berkesinambungan dengan bekerja sama bersama pihak-pihak terkait, sehingga diharapkan memberikan kontribusi atas terwujudnya peningkatan derajat kesehatan masyarakat pada umunya dan anak pada khususnya.
\end{abstract}

Kata kunci: Balita, deteksi dini, kader kesehatan, stunting.

\begin{abstract}
One of the health problems related to growth and development in children under five which may cause adverse effects in the short and long term is stunting. Recently, the government is trying to overcome stunting with specific nutritional intervention. In order for the program to run effectively, early detection of children with stunting is important to do and also stimulating growth and development in children. Based on data from Puskesmas Jatinangor, in Cipacing Village there were 14 children who were in stunting status. The purpose of this activity is to empower health cadres in early detection of stunting and stimulation of growth and development in children. The target of this activity is health cadres with a total sample of 31 people. Empowerment activities in the form of one training day divided into 3 sessions using lecture methods, discussion and question and answer as well as demonstrations and re-demonstrations by health cadres. The results showed that there was an increase in the knowledge of health cadres, before the activity $61.3 \%$ of the health cadres had good knowledge and after doing the activities increased to as much as 93.5\%. In addition, the results of statistical tests showed a significant increase in the knowledge of health cadres after the intervention $(p=0.000)$. However, for psychomotor aspects measured after training, almost half of the respondents are still in the unfavorable category. Therefore, it is expected that the activities of empowering health cadres in the early detection of stunting and stimulation of growth and development in children should be carried out continuously by cooperating with relevant parties, so that it will contribute on improvement of the health status of society in general and children in particular.
\end{abstract}

Keywords: Children, early detection, health cadre, stunting 
Fanny Adistie : Pemberdayaan Kader Kesehatan Dalam Deteksi Dini Stunting dan Stimulasi

\section{Pendahuluan}

Indonesia adalah negara berkembang yang memiliki permasalahan yang kompleks terutama dalam masalah gizi. Permasalah gizinya pun berbeda dengan negara maju, yaitu Indonesia memiliki masalah gizi ganda yang merupakan fenomena ironis, disaat tingginya kasus gizi buruk disisi lain terdapat kasus gizi lebih. Gizi kurang atau malnutrisi adalah kondisi kekurangan gizi akibat jumlah konsumsi mikronutrien dan makronutrien tidak mencukupi, yang tentu saja akan mempengaruhi kondisi keseimbangan mikro dan makronutrien. Salah satu penyebabnya adalah malabsorpsi (misal fibrosis kistik) yaitu ketidak mampuan mengonsumsi nutrient. Malnutrisi dapat menyebabkan penyakit seperti skorbut (malnutrisi akibat kekurangan asupan vitamin $\mathrm{C}$ dalam diet) atau obesitas (malnutrisi akibat asupan energi yang berlebihan) (Unicef, 2012).

Menurut Riset Kesehatan Dasar tahun 2013, Indonesia telah menunjukkan penurunan kemiskinan secara tetap, tetapi masalah gizi kurang yang berdampak buruk pada anak-anak menunjukkan sedikit perbaikan. Dari tahun 2007 sampai 2011, proporsi penduduk miskin di Indonesia mengalami penurunan sebesar $16,6-12,5 \%$, tetapi masalah gizi kurang tidak menunjukkan penurunan secara signifikan. Gizi kurang menyebabkan prevalensi stunting (anak pendek) sangat tinggi, mempengaruhi satu dari tiga anak 12 - 60 bulan, yang merupakan proporsi yang menjadi masalah kesehatan masyarakat menurut kriteria Organisasi Kesehatan Dunia (WHO) (Kementerian Kesehatan Republik Indonesia, 2013).

Stunting adalah masalah gizi kronis yang disebabkan oleh asupan gizi yang kurang dalam waktu cukup lama akibat pemberian makanan yang tidak sesuai dengan kebutuhan gizi (Millenium Challenge Account - Indonesia, 2018). Prevalensi stunting di Indonesia tercatat sebesar 37,2\%, meningkat dari tahun 2010 (35,6\%) dan tahun 2007 (36,8\%). Persentase tersebut dengan pembagian untuk kategori sangat pendek $19,2 \%$ dan pendek $18,1 \%$. Artinya, diperkirakan lebih dari sepertiga atau lebih dari 8,9 juta anak usia dibawah 5 tahun di Indonesia mengalami pertumbuhan yang tidak sesuai ukuran standar internasional untuk tinggi badan berbanding usia (Kementerian Kesehatan Republik Indonesia, 2013). Stunting menurut WHO Child Growth Standard didasarkan pada indeks panjang badan menurut umur $(\mathrm{PB} / \mathrm{U})$ atau tinggi badan menurut umur $(\mathrm{TB} / \mathrm{U})$ dengan batas $(\mathrm{z}$-score) $<-2$ SD (WHO, 2013).

Jawa Barat mempunyai angka prevalensi stunting sebesar 25,6\% pada tahun 2015, walaupun tidak terklasifikasikan sebagai masalah berat dalam riskesdas, namun angka ini termasuk cukup tinggi dan perlu ditangani agar terjadi penurunan prevalensi. Stunting pada balita memperlihatkan kondisi kesehatan yang buruk secara kronis, dan mempunyai dampak yang cukup membahayakan apabila tidak ditangani. Dampak buruk yang dapat ditimbulkan oleh masalah gizi pada periode tersebut, dalam jangka pendek adalah terganggunya perkembangan otak, kecerdasan, gangguan pertumbuhan fisik, dan gangguan metabolisme dalam tubuh. Sedangkan dalam jangka panjang akibat buruk yang dapat ditimbulkan adalah menurunnya kemampuan kognitif dan prestasi belajar, 
Fanny Adistie : Pemberdayaan Kader Kesehatan Dalam Deteksi Dini Stunting dan Stimulasi

menurunnya kekebalan tubuh sehingga mudah sakit, dan risiko tinggi untuk munculnya penyakit diabetes, kegemukan, penyakit jantung dan pembuluh darah, kanker, stroke, dan disabilitas pada usia tua, serta kualitas kerja yang tidak kompetitif yang berakibat pada rendahnya produktivitas ekonomi (Kementerian Kesehatan Republik Indonesia, 2016). Generasi penerus bangsa sudah selayaknya mendapatkan nutriasi yang cukup agar menjadi generasi yang cerdas dan pandai. Selain membenahi dalam hal nutrisi kita juga wajib meningkatkan kecerdasan dan tumbuh kembang pada anak agar generasi penerus bangsa dapat menjadi generasi yang bermutu (Kementerian Kesehatan Republik Indonesia, 2013).

BPB dari Puskesmas Jatinangor tahun 2017 tercatat bahwa terdapat 10 balita laki-laki yang mempunyai status gizi buruk berdasarkan berat $\mathrm{BB} / \mathrm{U}$ dan 36 balita yang memiliki status kurang, sedangkan untuk perempuan terdapat 7 balita yang berstatus buruk dan 28 yang berstatus kurang. Data tersebut diambil dari 7 desa yang berada di Jatinangor dan terdiri dari 1037 balita yang ditimbang. Berdasarkan data tersebut sehingga kami memilih satu desa yaitu desa Cipacing yang memiliki jumlah anak berstatus gizi kurang dan buruk yang lebih banyak yaitu 9 untuk laki-laki dan 5 untuk perempuan, diambil dari 165 balita yang ditimbang, untuk kami berikan penyuluhan Stunting kepada para kader.

Berdasarkan hasil wawancara kepada pihak Puskesmas Jatinangor, program yang pernah dilakukan terkait stunting adalah penapisan ibu hamil kurang energi kronis (KEK) dan anemia; pemberian makanan tambahan (PMT) ibu hamil KEK atau anemia; kelas ibu hamil; kelas ibu menyusui; konseling menyusui dan ASI eksklusif pada ibu yang melahirkan di puskesmas; sosialisasi pemberian makanan pada bayi dan anak (PMBA); pemberian MP-ASI pada bawah dua tahun keluarga miskin; pendampingan pemberian tablet tambah darah bagi remaja putri; serta pelatihan yang pernah dilakukan kepada kader adalah pelatihan tentang PMBA.

Program yang dilakukan untuk mencegah stunting lebih banyak difokuskan untuk ibu hamil, hal tersebut sangat baik mengingat dengan ibu hamil yang sudah mengetahui sedikit banyaknya terkait stunting dapat mencegah kejadian stunting. Tetapi, akan lebih baik jika pasca kehamilan pun baik ibu maupun kader dapat mengetahui tumbuh kembang anak. Terlihat sudah baik penyelenggaraan penimbangan di Desa Cipacing, namun para kader masih sekadar mencatat berat badan dan usia dari bayi ataupun balita itu saja. Dilakukannya pemberdayaan kepada kader di Desa Cipacing terkait stunting dilakukan agar ketika kader sedang mencatat berat badan anak tersebut, kader dapat segera mengetahui apakah anak tersebut termasuk kedalam kondisi stunting atau tidak. Hal ini dikarenakan fenomena saat ini, dalam melakukan kegiatan posyandu, kader hanya melakukan pengukuran berat badan dan tinggi badan lalu mencatat nya di buku kunjungan dengan tanpa melakukan interpretasi hasil pengukuran. Selain itu, terkait deteksi perkembangan serta stimulasi tumbuh kembang juga belum terlaksana pada kegiatan posyandu. Dengan kegiatan pemberdayaan kader ini diharapkan pendeteksian dini terkait stunting dan ada atau tidaknya penyimpangan perkembangan anak dapat 
Fanny Adistie : Pemberdayaan Kader Kesehatan Dalam Deteksi Dini Stunting dan Stimulasi

segera dilakukan sehingga kejadian stunting dan atau penyimpangan perkembangan dapat segera diatasi.

Memantau pertumbuhan balita di posyandu merupakan upaya yang sangat strategis untuk mendeteksi dini terjadinya gangguan pertumbuhan. Pencegahan dini adalah salah satu cara terbaik untuk mengurangi prevalensi stunting di jawa barat. Prosedur terpenting dari pencegahan dini adalah dilakukan screening rutin dan follow-up tinggi badan balita yang persisten. Program Posyandu yang dibuat oleh pemerintah sudah sangat baik dan menjadi solusi yang konkrit untuk menjangkau seluruh lapisan masyarakat. Semakin baik pelayanan yang dilakukan posyandu sebanding dengan peningkatan mutu kesehatan masyarakat. Proses screening rutin tinggi badan/umur sudah selayaknya menjadi agenda wajib dalam setiap kegiatan yang dilaksanakan di posyandu (Setyowati \& Retno, 2015).

Keterbatasannya tenaga kesehatan di Indonesia menyebabkan daya cakup pelayanan kesehatan belum optimal. Sehingga strategi pembangunan partisipatif adalah cara yang efektif untuk menangani masalah stunting ini. Dikatakan partisipatif karena bukan hanya pemerintah yang harus sadar dan beraksi, namun juga masyarakat harus sadar dan bergerak untuk menangani masalah ini. Salah satunya adalah dengan pembedayaan kader kesehatan di posyandu-posyandu yang ada. Kasus stunting terjadi biasanya karena penyakit ini tidak disadari dan diketahui oleh masyarakat. Sehingga masyarakat perlu pemberdayaan agar tahu dan juga mengerti tanda-tanda stunting. Apabila masyarakat tahu karakteristik stunting sejak dini, maka bisa segera dilakukan penanganan agar tidak menimbulkan komplikasi yang buruk. Selain itu, untuk mengoptimalkan tumbuh kembang anak masyarakat juga harus memahami pentingnya stimlasi tumbuh kembang anak.

Merujuk permasalahan diatas, maka kegiatan KKNM terintegrasi PPM yang kami laksanakan adalah untuk melakukan pemberdayaan kepada kader kesehatan yang ada di desa Cipacing jatinangor agar mampu untuk mendeteksi stunting sejak dini serta mampu melakukan stimulasi tumbuh kembang pada anak dengan baik. Sehingga nantinya, apabila stunting dapat dicegah sejak dini, dan juga stimulasi tumbuh kembang dapat dilaksanakan oleh kader-kader yang ada di Posyandu di Desa Cipacing Kecamatan Jatinangor, akan menjadi salah satu solusi konkrit dalam kontribusi pemecahan permasalahan gizi di Jawa Barat.

\section{Metode}

Kegiatan ini berupa pemberdayaan kader kesehatan dalam deteksi dini stunting serta stimulasi tumbuh kembang pada anak di Desa Cipacing, Kecamatan Jatinangor, Kabupaten Sumedang. Populasi pada kegiatan ini adalah para kader kesehatan di Desa Cipacing Kecamatan Jatinangor Kabupaten Sumedang dengan teknik pengambilan sampel menggunakan accidental sampling, sehingga didapatkan 31 orang kader kesehatan yang berpartisipasi pada kegiatan ini.

Tujuan dari kegiatan ini salah satunya adalah untuk mengidentifikasi peningkatan kemampuan kognitif serta psikomotor para kader kesehatan dalam deteksi dini stunting serta stimulasi tumbuh 
Fanny Adistie : Pemberdayaan Kader Kesehatan Dalam Deteksi Dini Stunting dan Stimulasi

kembang pada anak. Intervensi yang dilakukan pada kegiatan ini adalah dengan pemberian ceramah, diskusi, simulasi serta praktikum. Intervensi pada kegiatan ini dimulai dengan pembuatan modul mengenai deteksi dini stunting serta stimulasi tumbuh kembang dengan mengacu kepada modulmodul tentang stunting dan stimulasi tumbuh kembang anak dari Kementerian Kesehatan Indonesia. Modul ini yang akan digunakan oleh para kader kesehatan dalam melakukan deteksi dini stunting serta stimulasi tumbuh kembang pada anak. Dilanjutkan dengan diadakannya pelatihan bagi para fasilitator yang akan terlibat dalam kegiatan, selain itu diadakan interrater reliability terkait lembar checklist observasi yang akan digunakan dalam penilaian psikomotor kader kesehatan dalam melakukan deteksi dini stunting dan stimulasi tumbuh kembang pada anak. Kegiatan selanjutnya yaitu berupa pelatihan kepada para kader kesehatan. Pada kegiatan pelatihan ini para kader kesehatan mendapatkan ceramah materi mengenai deteksi dini stunting serta stimulasi tumbuh kembang pada anak selama 60 menit, dilanjutkan oleh sesi diskusi dan tanya jawab. Kegiatan selanjutnya adalah demonstrasi deteksi dini stunting serta stimulasi tumbuh kembang pada anak dengan menggunakan alat peraga yaitu alat pemeriksaan tinggi badan dan berat badan serta alat deteksi dan stimulasi tumbuh kembang (bola, benang wol, kerincingan, biscuit, pensil, kacang, kancing, kubus, alat makan plastik, boneka anak) selama 120 menit, kemudian para kader kesehatan dibagi ke dalam beberapa kelompok kecil (lima sampai enam kader tiap kelompok) dan didampingi oleh fasilitator untuk melakukan re-demonstrasi cara deteksi dini stunting serta stimulasi tumbuh kembang pada anak, dengan tujuan untuk meningkatkan kemampuan psikomotor para kader kesehatan. Setelah kegiatan pelatihan, kegiatan evaluasi pelaksanaa deteksi dini stunting serta stimulasi tumbuh kembang dilakukan saat posyandu berlangsung di RW masing-masing. Pada kegiatan ini setiap kader diberi modul deteksi dini stunting, modul stimulasi tumbuh kembang serta kit yang berisi alat untuk mendeteksi tumbuh kembang pada anak, untuk digunakan di posyandu masing-masing.

Pengetahuan kader kesehatan mengenai deteksi dini stunting serta stimulasi tumbuh kembang pada anak dilakukan dengan menggunakan kuesioner pretest dan posttest, sedangkan untuk pengukuran kemampuan psikomotor dilakukan dengan menggunakan lembar checklist observasi setelah kegiatan pelatihan selesai dilaksanakan. Data di analisis dengan menggunakan analisis univariat dengan distribusi freksuensi serta analisis bivariat dengan menggunakan uji Wilcoxon dikarenakan hasil uji normalitas data menunjukkan kedua data tidak berdistribusi normal. 
Fanny Adistie : Pemberdayaan Kader Kesehatan Dalam Deteksi Dini Stunting dan Stimulasi

Hasil

Tabel 1 Distribusi Frekuensi Pengetahuan Kader Kesehatan Mengenai Deteksi Dini Stunting serta Stimulasi Tumbuh Kembang Pada Anak di Desa Cipacing, Kecamatan Jatinangor, Kabupaten Sumedang, Sebelum dan Sesudah Intervensi (N=31)

\begin{tabular}{lcccccc}
\hline \multirow{2}{*}{ Pengetahuan } & \multicolumn{2}{c}{ Kurang } & \multicolumn{2}{c}{ Cukup } & \multicolumn{2}{c}{ Baik } \\
\cline { 2 - 7 } Kader Kesehatan & Frekuensi & Prosentase & Frekuensi & Prosentase & Frekuensi & Prosentase \\
& $(\boldsymbol{f})$ & $(\boldsymbol{\%})$ & $(\boldsymbol{f})$ & $(\boldsymbol{\%})$ & $(\boldsymbol{f})$ & $(\boldsymbol{\%})$ \\
\hline Sebelum & 0 & 0 & 12 & 38,7 & 19 & 61,3 \\
Sesudah & 0 & 0 & 2 & 6,5 & 29 & 93,5 \\
\hline
\end{tabular}

Pada tabel diatas menunjukkan bahwa sebelum diberikan intervensi tingkat pengetahuan kader kesehatan mengenai deteksi dini stunting serta stimulasi tumbuh kembang berada pada kategori baik sebanyak $61,3 \%$ dan setelah diberikan intervensi tigkat pengetahuan kader kesehatan yang berada pada kategori baik menjadi sebanyak 93\%.

Tabel 2 Pengukuran Pengetahuan Kader Kesehatan Mengenai Deteksi Dini Stunting serta Stimulasi Tumbuh Kembang Pada Anak di Desa Cipacing, Kecamatan Jatinangor, Kabupaten Sumedang $(\mathbf{N}=\mathbf{3 1})$

\begin{tabular}{lccc}
\hline $\begin{array}{l}\text { Pengetahuan Kader } \\
\text { Kesehatan }\end{array}$ & Mean Rank & Z hitung & Nilai $\boldsymbol{p}$ \\
\hline Sebelum & 15,3 & $-3,565$ & 0,000 \\
Sesudah & 8,3 & & \\
\hline
\end{tabular}

Hasil uji statistik pada tabel 2 menunjukkan terdapat peningkatan yang signifikan pada pengetahuan kader kesehatan setelah dilakukan intervensi melalui kegiatan pelatihan kader kesehatan dalam deteksi dini stunting serta stimulasi tumbuh kembang pada anak $(p=0,000 ; \alpha<0,05)$.

Tabel 3 Distribusi Frekuensi Pengukuran Kemampuan Psikomotor Kader Kesehatan dalam Melakukan Deteksi Dini Stunting serta Stimulasi Tumbuh Kembang Pada Anak di Desa Cipacing, Kecamatan Jatinangor, Kabupaten Sumedang ( $N=31)$

\begin{tabular}{lcc}
\hline \multicolumn{1}{c}{ Kategori } & Frekuensi $(\boldsymbol{f})$ & Prosentase (\%) \\
\hline Baik & 18 & 58,1 \\
Kurang Baik & 13 & 41,9 \\
\hline
\end{tabular}

Selanjutnya pada tabel 3 tergambar hasil pengukuran kemampuan psikomotor kader kesehatan dalam melakukan deteksi dini stunting serta stimulasi tumbuh kembang pada anak. Kegiatan ini diukur 
Fanny Adistie : Pemberdayaan Kader Kesehatan Dalam Deteksi Dini Stunting dan Stimulasi

dengan menggunakan lembar checklist observasi dengan pengukuran yang dilakukan satu kali setelah para kader kesehatan mengikuti pelatihan. Berdasarkan tabel diatas, kemampuan psikomotor kader kesehatan dalam melakukan deteksi dini stunting serta stimulasi tumbuh kembang pada anak menunjukkan bahwa sebanyak 41,9\% kader kesehatan masih berada pada kategori kurang baik dalam melakukan deteksi dini stunting serta stimulasi tumbuh kembang pada anak. Pada saat dilakukan observasi, terlihat bahwa para kader kesehatan tersebut masih belum mampu melakukan dengan baik penentuan stunting pada anak serta belum mampu melakukan dengan baik beberapa butir stimulasi perkembangan pada anak.

\section{Pembahasan}

Merujuk hasil diatas terlihat bahwa terdapat peningkatan pengetahuan para kader kesehatan sebelum dan setelah dilakukan intervensi. Sebelum dilakukan intervensi, hampir setengah dari para kader kesehatan memiliki tingkat pengetahuan pada kategori cukup dan tidak terdapat kader yang tingkat pengetahuannya berada pada kategori kurang. Setelah dilakukan intervensi, hanya sebagian kecil dari para kader kesehatan yang masih memiliki tingkat pengetahuan yang cukup mengenai deteksi dini stunting serta stimulasi tumbuh kembang pada anak. Berdasarkan hasil wawancara pada saat melakukan kajian situasi, pihak puskesmas jatinangor mengatakan tingkat partisipasi para kader kesehatan Desa Cipacing cukup baik dalam mengikuti kegiatan-kegiatan penyuluhan yang diadakan baik oleh puskesmas maupun instansi lain. Hal ini yang mungkin menjadi penyebab tidak terdapatnya kader kesehatan yang memiliki tingkat pengetahuan yang kurang terkait deteksi dini stunting dan stimulasi tumbuh kembang anak. Para kader kesehatan telah sering terpapar informasi terkait kesehatan baik dari puskesmas maupun dari instansi lain. Informasi yang di peroleh dari berbagai sumber akan mempengaruhi tingkat pengetahuan seseorang, sehingga bila seseorang banyak memperoleh informasi maka ia cenderung mempunyai pengetahuan yang lebih luas (Notoatmodjo, 2007).

Hasil uji statistik menunjukkan bahwa kegiatan pelatihan yang diberikan kepada para kader kesehatan memberikan pengaruh terhadap peningkatan pengetahuan para kader kesehatan. Metode yang diberikan pada kegiatan ini antara lain ceramah dan diskusi, simulasi serta praktikum. Berdasarkan hasil tersebut, metode ceramah dirasa efektif dalam meningkatkan pengetahuan para kader kesehatan. Seperti hasil penelitian yang dilakukan oleh Sarwani, Nurhayati, dan Supriyanto (2014), yang menyimpulkan bahwa terdapat perbedaan pengetahuan kader kesehatan kecamatan Pukencen dan kecamatan Sumbang Kabupaten Banyumas tentang penyakit talasemia sebelum dan sesudah diberikan ceramah mengenai talasemia. Selain itu, hasil penelitian yang dilakukan oleh Pramiputra (2014), juga menunjukkan adanya perbedaan pengetahuan sebelum dan sesudah dilakukan kegiatan ceramah tentang pencegahan demam berdarah dengue di desa Wonorejo Polokarto. 
Fanny Adistie : Pemberdayaan Kader Kesehatan Dalam Deteksi Dini Stunting dan Stimulasi

Pada kegiatan ini metode pengajaran yang diberikan pada para kader kesehatan tidak hanya dengan menggunakan metode ceramah, namun menerapkan metode lain diantaranya diskusi, simulasi serta praktikum. Penerapan metode-metode ini saling menunjang tercapainya tujuan pembelajaran yang diharapkan. Metode ceramah merupakan suatu metode pengajaran dengan menyampaikan informasi dan pengetahuan secara lisan kepada sejumlah sasaran yang memungkinkan semua sasaran mendengar informasi yang sama dengan cara yang sama dalam kurun waktu yang terbatas (Nursalam, 2008). Metode ini mempunyai kelebihan dapat dipakai pada orang dewasa, menghabiskan waktu dengan baik, dapat digunakan pada kelompok besar, tidak melibatkan banyak alat bantu, pendidik mudah menguasai kelas serta mudah menerangkan banyak bahan ajar dan mudah dilaksanakan (Nursalam, 2008; Simamora, 2009). Namun, metode ini juga memiliki kelemahan yaitu dapat membuat peserta didik menjadi pasif, mengandung unsur paksaan kepada peserta didik, mengandung sedikit daya kritis peserta didik, serta bagi peserta didik dengan tipe belajar visual akan lebih sulit menerima apa yang diajarkan dibandingkan dnegan peserta didik yang memiliki tipe belajar audio, selain itu, sulit untuk mengendalikan sejauh mana pemahaman peserta didik, serta jika terlalu lama dapat membuat jenuh peserta didik (Simamora, 2009).

Untuk itu, pada kegiatan ini metode pengajaran yang diberikan merupakan kombinasi dari beberapa metode diatas. Dengan disertai metode diskusi, simulasi serta praktikum, diharapkan dapat mengatasi kelemahan dari metode ceramah tersebut. Tujuan dari metode diskusi adalah mendorong peserta didik untuk berpikir kritis, mengekspresikan pendapatnya dengan bebas, menyumbangkan pemikirannya untuk memecahkan masalah bersama serta mengambil satu atau beberapa alteratif jawaban untuk pemecahan masalah dengan pertimbangan yang cermat (Simamora, 2009). Sehingga sasaran dapat bertanya dan mendapat penjelasan dari hal-hal yang masih belum dipahami. Selain itu, pada kegiatan ini juga dilaksanakan metode demonstrasi cara melakukan deteksi dini stunting dan stimulasi tumbuh kembang pada anak. Metode demonstrasi dilakukan dengan cara memperagakan benda, kejadian, aturan, dan urutan melakukan suatu kegiatan, baik secara langsung maupun melalui penggunaan media pengajaran yang relevan dengan pokok bahasan atau materi yang disajikan (Simamora, 2009). Dengan begitu diharapkan, sasaran dapat mengetahui dan memahami setiap tahapan serta cara melakukan deteksi dini stunting dan stimulasi tumbuh kembang pada anak. Pada kegiatan ini, para kader kesehatan juga melakukan demonstrasi ulang cara melakukan deteksi dini stunting dan stimulasi tumbuh kembang pada anak sesuai dengan apa yang telah di ajarkan dengan bimbingan dari fasilitator, dengan tujuan retensi pengetahuan terkait hal diatas akan lebih optimal. Seperti yang dingkapkan oleh Aisyaroh, Susiloningtyas, dan Mubarok (2017), yang menyebutkan bahwa Tingkat pemahaman kader dari hasil pretest dan posttest meningkat sebesar $1,45 \%$ setelah diberikan intervensi dengan metode demonstrasi mengenai MP-ASI. Selain itu, Astuti (2013), juga menyebutkan bahwa metode ceramah interaktif dan demonstrasi disertai dengan alat peraga memiliki pengaruh dalam peningkatan pengetahuan dan keterampilan komunikasi guru serta terdapat perbedaan 
Fanny Adistie : Pemberdayaan Kader Kesehatan Dalam Deteksi Dini Stunting dan Stimulasi

tingkat pengetahuan dan keterampilan komunikasi guru pada kelompok perlakuan dan kontrol pada kegiatan promosi kesehatan gigi dan mulut.

Peningkatan pengetahuan para kader kesehatan ini sangat diharapkan karena pengetahuan pengetahuan diperlukan sebagai dorongan fisik untuk menumbuhkan rasa percaya diri maupun sikap perilaku seseorang, sehingga pengetahuan bisa merupakan domain yang sangat penting terhadap terbentuknya tindakan seseorang (Notoatmodjo, 2012). Pengetahuan atau kognitif merupakan domain yang sangat penting dalam membentuk tindakan seseorang (overtbehaviour) (Effendi \& Makhfudli, 2009). Berdasarkan beberapa hasil penelitian menunjukkan bahwa perilaku juga didasari oleh tingkat pengetahuan seseorang. Penelitian yang dilakukan oleh Fatmah dan Nasution (2012), menyimpulkan bahwa tingkat keterampilan kader posbindu dalam melakukan pengukuran antropometri tinggi badan prediksi lansia dan penyuluhan gizi seimbang dan hipertensi lansia berhubungan dengan peningkatan pengetahuan sebelum dan setelah pelatihan.

Maka dari itu, para kader diharapkan dapat mampu melakukan dengan baik atau meningkat aspek psikomotornya dalam melakukan deteksi dini stunting setelah diberikan wawasan serta pengetahuan melalui kegiatan pelatihan. Walaupun pada hasil observasi terkait kemampuan psikomotor masih terdapat kader yang memiliki kemampuan psikomotor kurang baik sebanyak 41,9\%. Hal ini juga bisa dipengaruhi oleh faktor-faktor lain. Salah satunya bisa dikarenakan jumlah pertemuan pada kegiatan pemberdayaan ini. Suatu penelitian yang dilakukan oleh Fitri M dan Mardiana (2011), menyebutkan bahwa ada perbedaan keterampilan kader posyandu dalam pengukuran antropometri sebelum dan sesudah pelatihan selama 4 kali pertemuan. Sementara pada kegiatan ini, pelatihan hanya dilakukan pada 1 kali pertemuan. Faktor lainnya kemungkinan terkait dengan motivasi dari kader itu sendiri. Penelitian kepada kader kesehatan terkait aktivitas dalam pengendalian kasus Tuberkulosis yang dilakukan oleh Wijaya, Murti, dan Suriyasa (2013), menyebutkan bahwa beberapa faktor yang berhubungan dengan aktivitas kader kesehatan dalam pengendalian Tuberkulosis di Kabupaten Buleleng adalah pengetahuan, sikap serta motivasi dari kader kesehatan tersebut. Sementara kegiatan pemberdayaan kader kesehatan yang kami laksanakan belum menyertakan identifikasi sikap serta motivasi dari para kader kesehatan tersebut. Sehingga hal tersebut bisa menjadi kemungkinan masih adanya kemampuan psikomotor kader kesehatan yang kurang baik walaupun tingkat pengetahuannya hampir seluruhnya berada pada kategori baik.

Merujuk pembahasan diatas, metode yang diterapkan pada kegiatan pemberdayaan kesehatan efektif dalam meningkatkan pengetahuan kader kesehatan tentang deteksi dini stunting serta stimulasi tumbuh kembang. Namun, terkait kemampuan psikomotor kader kesehatan dalam melakukan deteksi dini stunting serta stimulasi tumbuh kembang pada anak masih perlu dilakukan upaya-upaya yang dapat mendukung peningkatan kemampuan psikomotor para kader tersebut selain dengan peningkatan pengetahuan melalui pelatihan. Upaya-upaya tersebut adalah dengan melakukan kerjasama dengan berbagai pihak terutama Puskesmas Kecamatan Jatinangor dalam hal: 
Fanny Adistie : Pemberdayaan Kader Kesehatan Dalam Deteksi Dini Stunting dan Stimulasi

1. Edukasi berkelanjutan, misalnya setiap 6 bulan sekali untuk kader serta kegiatan penguatan peran para kader kesehatan secara rutin terutama terkait stunting dan tumbuh kembang anak sebagai upaya meningkatkan pengetahuan serta keterampilan kader kesehatan.

2. Monitoring dan evaluasi yang dilakukan secara rutin oleh pihak puskesmas terhadap para kader kesehatan dalam pelaksanaan penimbangan, deteksi status gizi maupun deteksi serta stimulasi tumbuh kembang anak.

3. Optimalisasi pelaporan seperti cara pencatatan yang efektif dan jelas disertai hasil interpretasi pengukuran serta kecepatan dalam penyerahan laporan hasil deteksi dini tumbuh kembang anak serta status gizi dan deteksi stunting dari para kader kesehatan kepada bidan desa setempat atau puskesmas.

4. Pemberian reward kepada kader kesehatan yang berperan aktif dalam melakukan deteksi dini stunting serta deteksi dini dan stimulasi tumbuh kembang anak sehingga dapat memotivasi kader kesehatan lain dalam meningkatkan performanya.

Peran aktif para kader kesehatan dalam membantu masyarakat untuk melakukan deteksi dini stunting serta stimulasi tumbuh kembang pada anak sehat dan melakukan kerjasama dengan pihak puskesmas dan dinas terkait untuk melakukan pelaporan memberikan kontribusi atas terwujudnya peningkatan derajat kesehatan masyarakat. anak dengan stunting atau berisiko stunting, serta anak dengan risiko penyimpangan atau gangguan tumbuh kembang dapat segera mendapatkan penanganan dengan cepat dan tepat sehingga dapat membantu mencegah atau meminimalisir dampak yang merugikan pada anak maupun keluarga serta menurunkan angka morbiditas. di wilayah tersebut.

\section{Simpulan}

Pelaksanaan pemberdayaan kader kesehatan dalam deteksi dini stunting serta stimulasi tumbuh kembang anak di Desa Cipacing telah terlaksana dengan lancar dan mendapat dukungan dari Puskesmas Kecamatan Jatinangor serta perangkat Desa Cipacing. Para kader kesehatan juga turut berpartisipasi dengan baik pada pelaksanaan kegiatan ini. Kegiatan yang telah dilakukan antara lain: dimulai dengan pembuatan modul mengenai deteksi dini stunting serta stimulasi tumbuh kembang, pelatihan bagi para fasilitator yang akan terlibat dalam kegiatan, lalu pelatihan kepada para kader kesehatan dengan menggunakan metode ceramah, diskusi dan tanya jawab serta demonstrasi cara melakukan deteksi dini stunting serta stimulasi tumbuh kembang pada anak dengan menggunakan alat peraga, kemudian para kader kesehatan dibagi-bagi ke dalam beberapa kelompok kecil dan didampingi oleh fasilitator untuk melakukan re-demonstrasi cara deteksi dini stunting serta stimulasi tumbuh kembang pada anak. Setelah kegiatan pelatihan, kegiatan evaluasi pelaksanaan deteksi dini stunting serta stimulasi tumbuh kembang dilakukan saat posyandu berlangsung di RW masingmasing. 
Fanny Adistie : Pemberdayaan Kader Kesehatan Dalam Deteksi Dini Stunting dan Stimulasi

Hasil kegiatan menunjukkan bahwa terdapat peningkatan pengetahuan para kader kesehatan yaitu sebelum dilakukan kegiatan sebanyak $61,3 \%$ kader kesehatan yang memiliki pengetahuan yang baik dan setelah dilakukan kegiatan, kader kesehatan yang memiliki tingkat pengetahuan yang baik meningkat menjadi sebanyak 93,5\%. Selain itu, hasil uji statistik menunjukkan terdapat peningkatan yang signifikan pada pengetahuan kader kesehatan setelah dilakukan intervensi melalui kegiatan pelatihan kader kesehatan dalam deteksi dini stunting serta stimulasi tumbuh kembang pada anak ( $p=$ 0,000). Hal ini menunjukkan bahwa pelatihan yang telah dilaksanakan efektif dalam meningkatkan pengetahuan para kader kesehatan mengenai deteksi dini stunting serta stimulasi tumbuh kembang pada anak. Namun, untuk aspek psikomotor hampir setengah dari jumlah responden masih berada pada kategori kurang baik dalam mengaplikasikan pelaksanaan deteksi dini stunting serta stimulasi tumbuh kembang pada anak.

Maka dari itu diharapkan kegiatan pemberdayaan kader kesehatan dalam stunting serta stimulasi tumbuh kembang pada anak sebaiknya dilakukan secara berkesinambungan dengan bekerja sama bersama pihak-pihak terkait, sehingga diharapkan memberikan kontribusi atas terwujudnya peningkatan derajat kesehatan masyarakat pada umunya dan ank pada khususnya.

\section{Ucapan Terima kasih}

Ucapan terimakasih kami sampaikan kepada para kader kesehatan di Desa Cipacing, Kecamatan Jatinangor yang telah bersedia berpartisipasi pada kegiatan ini, juga kepada pihak Puskesmas Kecamatan Jatinangor serta perangkat Desa Cipacing atas kerjasasamanya serta kontribusi dari para mahasiswa KKN. Kegiatan pengabdian kepada masyarakat ini mendapat dukungan dana dari Universitas Padjadjaran.

\section{Daftar Pustaka}

Aisyaroh, N., Susiloningtyas, I., \& Mubarok. (2017). Pengembangan Intervensi MP-ASI dengan Metode Demonstrasi pada Kader Posyandu Di Desa Batur Kecamatan Getasan Kabupaten Semarang. Prosiding Implementasi Penelitian Pada Pengabdian Menuju Masyarakat Mandiri Berkemajuan (pp. 573-577). Semarang: Universitas Muhammmadiyah Semarang.

Astuti, N. R. (2013). Promosi Kesehatan Gigi dan Mulut dengan Metode Ceramah Interaktif dan Demonstrasi Disertai Alat Peraga pada Guru Sekolah Dasar Sebagai Fasilitator. International Dental Journal, 2(2), 16-25.

Effendi, F., \& Makhfudli. (2009). Keperawatan Kesehatan Komunitas: Teori dan Praktik dalam Keperawatan. Jakarta: Salemba Medika.

Fatmah, F., \& Nasution, Y. (2012). Peningkatan Pengetahuan dan Keterampilan Kader Posbindu dalam Pengukuran Tinggi Badan Prediksi Lansia, Penyuluhan Gizi Seimbang dan Hipertensi Studi Di Kecamatan Grogol Petamburan, Jakarta Barat. Media Medika Indonesiana, 46(1), 6168.

Fitri M, H., \& Mardiana. (2011). Pelatihan Terhadap Keterampilan Kader Posyandu. KEMAS, 7(1), 
Fanny Adistie : Pemberdayaan Kader Kesehatan Dalam Deteksi Dini Stunting dan Stimulasi

22-27. https://doi.org/https://doi.org/10.15294/kemas.v7i1.1789

Kementerian Kesehatan Republik Indonesia. (2013). Riset Kesehatan Dasar 2013. Jakarta: Kementerian Kesehatan RI.

Kementerian Kesehatan Republik Indonesia. (2016). Situasi Balita Pendek. Jakarta: Pusat Data dan Informasi Kementerian Kesehatan RI.

Millenium Challenge Account - Indonesia. (2018). Stunting dan Masa Depan Indonesia. Jakarta: MCA - Indonesia.

Notoatmodjo, S. (2007). Kesehatan Masyarakat Ilmu dan Seni. Jakarta: Karya Medika.

Notoatmodjo, S. (2012). Promosi Kesehatan dan Perilaku Kesehatan. Jakarta: Rineka Cipta.

Nursalam. (2008). Konsep dan Penerapan Metodologi Penelitian Ilmu Keperawatan, Pedoman Skripsi, Tesis dan Intrumen Penelitian Keperawatan. Jakarta: Salemba Medika.

Pramiputra, A. (2014). Efektifitas Pendidikan Kesehataan Menggunakan Metode Ceramah dengan Leaflet Terhadap Peningkatan Pengetahuan Pencegahan Demam Berdarah Dengue Di Desa Wonorejo Polokarto. Diakses dari Universitas Muhammadiyah Surakarta, http://eprints.ums.ac.id/32335/13/2. NASKAH PUBLIKASI.pdf

Sarwani, D., Nurhayati, N., \& Supriyanto. (2014). Efektifitas Ceramah terhadap Pengetahuan Kader Kesehatan tentang Penyakit Talasemia di Kecamatan Pekuncen dan Kecamatan Sumbang Kabupaten Banyumas. $\quad$ Kesmas, $8(1), \quad$ 29-36. https://doi.org/http://dx.doi.org/10.12928/kesmas.v8i1.1038

Setyowati, M., \& Retno, A. (2015). Pemetaan Status Gizi Balita dalam Mendukung Keberhasilan Pencapaian Millenium Development Goals (MDGs). J Kesehat Masy, 10(2), 110-21.

Simamora, H. R. (2009). Buku Ajar Pendidikan dalam Keperawatan. Jakarta: EGC.

Unicef. (2012). Ringkasan Kajian Kesehatan Ibu dan Anak. Jakarta: UNICEF Indonesia.

WHO. (2013). Child Growth Indicators and Their Interpretation. http://www.who.int/\%0Anutgrowthdb/about/introduction/en/\%0Aindex2.html. Diakses tanggal 3 April 2018

Wijaya, I. M. K., Murti, B., \& Suriyasa, P. (2013). Hubungan Pengetahuan, Sikap, dan Motivasi Kader Kesehatan dengan Aktivitasnya dalam Pengendalian Kasus Tuberkulosis Di Kabupaten Buleleng. Jurnal Magister Kedokteran Keluarga, 1(1), 38-48. 